\title{
Pemberian Propolis terhadap Mempercepat Penyembuhan Luka Perineum pada Ibu Postpartum
}

\author{
Propolis Administration to Accelerate Perineum Wound Healing in Postpartum
}

\author{
Gangsar Indah Lestari ${ }^{1}{ }^{\otimes}$, M. Ridwan ${ }^{1}$, Firda Fibrila ${ }^{1}$ \\ ${ }^{1}$ Prodi Kebidanan Metro, Politeknik Kesehatan Tanjungkarang, Indonesia \\ $\bowtie$ Corresponding author e-mail: ridwan@poltekkes-tjk.ac.id, Alamat: Jl. Brigjend. Soetiyoso No 1, Metro Pusat, Lampung, \\ Indonesia 34111
}

\begin{tabular}{l}
\hline Articlel History: \\
Received April 30, 2020 \\
Revised Mei 2020 \\
Accepted Juni 29, 2020 \\
Keyword: \\
Healing wounds of perineum; \\
Mother pospartum; Propolis.
\end{tabular}

Kata kunci:

Penyembuhan luka perineum; Ibu pospartum; Propolis.

\begin{abstract}
Abstrak
Background: The management of the perineum wound is not good to cause infections that affect the prolonged healing of perineum wounds. Purpose: Research aims to determine the effect of giving propolis on the length of healing of perineum wounds in postpartum mothers. Method: Research using Completely Randomized Design. The subject of the study was the post partum mother who suffered perineum wounds. Sample cases as much as 39 and control samples as much as 39 , the total samples of 79 postpartum mothers. Samples taken in Non Random sample in the form of Acidental sampling initiated a sample group of cases then sample control group according to criteria of inclusion and exclusion of research. Data analysis using T-Test test (Paired T-Test). Result: Research shows the average degree of wound perineum in mothers group given propolis of 1.82 whereas in mothers who are not given propolis of 1.85. The average length of wound healing of perineum in mothers group given Propolis is 3.38 day while on a mother who is not given propolis of 1.85 and obtained $p$ value $=$ 0.000 ( $\leq$ alpha 0.05). Conclusion: Perineum wound in postpartum mothers given propolis will be healed faster than those who are not given propolis. Midwives while giving care to the mother post partum with perineum wounds can utilize propolis to accelerate the healing process while observing nutrition, personal hygiene, and consider the economic and ethical aspects.
\end{abstract}

\begin{abstract}
Abstrak
Latar belakang: Penatalaksanaan luka perineum tidak baik menyebakan infeksi yang berpengaruh terhadap lama penyembuhan luka perineum. Tujuan: Penelitian bertujuan mengetahui pengaruh pemberian propolis terhadap lama penyembuhan luka perineum pada ibu postpartum. Metode: Penelitian menggunakan rancangan completely randomized design. Subyek penelitian adalah ibu post partum yang mengalami luka perineum. Sampel kasus sebanyak 39 dan sampel kontrol sebanyak 39, total sampel 79 ibu postpartum. Sampel diambil secara non random sample berupa acidental sampling dimulai sampel kelompok kasus lalu sampel kelompok kontrol sesuai kriteria inklusi dan eksklusi penelitian. Analisis data mengunakan uji T-Test (paired t-test). Hasil: Penelitian menunjukkan rata-rata derajat luka perineum pada kelompok ibu yang diberi propolis sebesar 1,82 sedangkan pada ibu yang tidak diberi propolis sebesar 1,85 . Ratarata lama penyembuhan luka perineum pada kelompok ibu yang diberi propolis adalah 3,38 hari sedangkan pada ibu yang tidak diberi propolis sebesar 1,85 dan didapatkan $\mathrm{p}$ value $=0,000(\leq$ alpha 0,05$)$. Simpulan: Luka perineum pada ibu postpartum yang diberi propolis akan lebih cepat sembuh dibanding dengan yang tidak diberi propolis. Bidan saat memberikan asuhan pada ibu post partum dengan luka perineum bisa memanfaatkan propolis guna mempercepat proses penyembuhan dengan tetap memperhatikan nutrisi, personal hygiene dan mempertimbangkan aspek ekonomis dan etika.
\end{abstract}

Copyright (C) 2020 Jurnal Kesehatan Metro Sai Wawai All rights reserved. 


\section{Pendahuluan}

Proses persalinan seorang wanita sering kali menyebabkan robekan/ruptur perineum yang terjadi pada hampir semua persalinan pertama dan tidak jarang juga terjadi pada persalinan berikutnya umumnya karena perineum yang kaku (Manuaba, 2010). Ruptur perineum merupakan robekan pada jalan lahir maupun karena episiotomi pada saat melahirkan janin. Ruptur perineum terjadi pada hampir semua persalinan pertama dan tidak jarang juga terjadi pada persalinan berikutnya. Perineum merupakan bagian permukaan pintu bawah panggul, yang terletak antara vulva dan anus (Wiknjosastro, 2010).

Kejadian ruptur perineum di dunia sebesar 2,7 juta pada ibu bersalin. Diestimasi tahun 2050. mencapai sampai 6,3 juta. Sedangkan, di Asia kasus ruptur perineum merupakan masalah yang besar terjadi di masyarakat. Sebesar $50 \%$ dari kasus ruptur perineum di dunia terjadi di Asia. Adapun di indonesia ibu bersalin dengan ruptur perineum berdasarkan umur 25-30 tahun berjumlah 24\% dan usia 32 -39 tahun terdapat $62 \%$ (Rahmawati, 2011). Prevalensi ibu bersalin yang mengalami rupture perineum di Indonesia sebesar 62\% pada kelompok umur 32 - 39 tahun dan $24 \%$ pada kelompok umur 25-30 (Afandi, 2014). Berdasarkan penyebab kasus kematian ibu di Provinsi Lampung tahun 2015, sebanyak 0,35\% disebabkan oleh infeksi puerperieum (Dinas Kesehatan Provinsi Lampung, 2016). Hasil survey di BPM Eka Santi Prabekti dan Sulistiyo Rahayu Kelurahan Pujokerto Lampung Tengah bulan Maret 2019 terdapat 56\% (9 ibu) dari 16 ibu bersalin mengalami luka perineum, bulan April 2019 terdapat 59\% (16 Ibu) dari $27 \mathrm{ibu}$ bersalin dan mengalami luka perineum, sedangkan bulan Mei 2019 mengalami kenaikan kasus luka perineum sebesar 71\% (12 Ibu) dari $17 \mathrm{ibu}$ bersalin.

Faktor penyebab terjadinya infeksi pada ibu postpartum berasal dari perlukaan pada jalan lahir. Robekan perineum terjadi pada hampir semua persalinan pertama dan tidak jarang juga pada persalinan berikutnya (Fraser, 2009). Luka perineum saat seorang ibu melahirkan bisa terjadi karena tindakan episiotomi maupun karena robeknya perineum saat kepala bayi keluar dari vagina. Penyembuhan luka perineum dapat terjadi dalam waktu 7 hari. Penatalaksanaan yang baik dapat menghindarkan kejadian infeksi. Oleh karena itu dalam masa nifas kebersihan ibu harus dijaga untuk mencegah terjadi komplikasi dan infeksi (Oxorn, 2010).

Hasil penelitian telah banyak menunjukkan penatalaksanaan penyembuhan luka perineum menggunakan antiseptik farmakologis, sedangkan hasil penelitian penggunaan antiseptik non farmakologis masih sangat jarang dilakukan. Antiseptik yang digunakan pada perawatan luka perineum dapat dilakukan dengan metode non farmakologi, salah satunya adalah propolis (Novita, 2019). Propolis merupakan zat resin yang dihasilkan oleh lebah dan merupakan percampuran dari air liur lebah, lilin lebah, dan juga bahan yang bersumber dari tanaman yang dibawa oleh lebah. Dari sekian banyak senyawa yang terkandung dalam propolis, salah satu yang paling dominan adalah polifenol. Senyawa yang satu ini merupakan antioksidan yang sangat baik untuk menangkal berbagai radikal bebas dan juga berbagai penyakit (Pusat, 2018). Beberapa khasiat propolis yang masih dimanfaatkan hingga saat ini adalah untuk mempercepat penyembuhan luka. Kandungan lain dalam propolis juga membuat propolis memiliki sifat antibakeri, antivirus, antifungal, dan antiinflamasi (Swari, 2016). Hasil penelitian yang dilakukan oleh Suyati, Azizah \& Ninik (2014), menemukan ada pengaruh pemanfaatan propolis terhadap penyembuhan luka perineum pada ibu postpartum. Penelitian ini bertujuan untuk mengetahui pengaruh pemberian propolis terhadap lama penyembuhan luka perineum pada ibu postpartum

\section{Metode}

Penelitian ini menggunakan rancangan quasi eksperimen (Murti, 2016). Populasi penelitian ini adalah seluruh ibu postpartum yang mengalami luka perineum. Berdasarkan hitung besar sampel beda proporsi satu kelompk diperoleh sampel kelompok ekperimen berjumlah 39 orang dan kelompok 
kontrol 39 orang (perbandingan 1:1), sehingga jumlah populasi 79 ibu postpartum. Pengambilan sampel menggunakan non random sample dengan teknik acidental sampling dimana setelah semua sampel kelompok kasus terpenuhi jumlahnya, dilanjutkan dengan pengambilan sampel kelompok kontrol sesuai kriteria inklusi yaitu : bersedia untuk dilakukan intervensi dan mengikuti prosedur penelitian seperti membasuh kemaluan menggunakan propolis, ibu yang mengalami luka perineum derajat I, II dan III dan ibu dengan luka perineum spontan dan episiotomi. Sedangkan kriteria eksklusinya yaitu : ibu postpartum dengan diabetes melitus, ibu postpartum dengan kelainan pembekuan darah dan mengalami luka perineum derajat IV.

Data yang dikumpulkan merupakan data primer yang diperoleh hasil obsertasi menggunakan lembar check list. Penelitin dilakukan pada bulan Agustus sampai Oktober 2019. Setelah responden memenuhi ketentuan insklusi dan eksklusi diberikan infom konsen kesediaan menjadi responden. Pertama kali yang dikumpulkan pada kelompok kasus sampai dengan jumlah sampel kasus terpenuhi setelah itu baru diambil kelompok kontrol sampai jumlah sampel kontrol terpenuhi. Prosedur kelompok kasus setelah postpartum hari pertama luka perineum diberi propolis melia kemasan $6 \mathrm{ml}$ yang diberikan semua ibu postpartum kelompok kasus. Pengolesan propolis di daerah luka perineum sesuai SOP yang telah ditetapkan. Pengolesan luka perineum dilakukan selama 7 hari postpartum yang dilakukan oleh petugas yang telah ditunjuk. Evaluasi perkembangan penyembuhan luka perineum dilakukan setiap hari pada saat dilakukan mengolesan luka perineum dan dicatat pada lembar observasi yang telah disiapkan. Sedangkan pada kelompok kontrol dimulai hari pertama sampai dengan hari ke 7 luka perineum tidak diberikan propolis hanya dilakukan pemersihan luka perineum saat vulva hygiene.

Analisis data dilakukan setelah dilakukan uji kenormalan data menggunakan uji kolmogorovsmirnov diperoleh data berdistribusi tidak normal ( $p$-value $=0,004)$, sehingga analisis univariat menggunakan mean dan analisis bivariat dilakukan menggunakan uji-t dependen non parametrik dengan willcoxon signed-rank test untuk mengetahui pengaruh pemberian propolis terhadap lama penyembuhan luka perineum pada ibu postpartum

\section{Hasil}

\section{Karakteristik responden}

Karakteritik responden pada tabel 1 pada kelompok ekperimen, yaitu diberikan propolis terdapat tiga perempat $(74,4 \%)$ berusia $20-35$ tahun, pekerjaan ibu yang dominan $(97,4 \%)$ sebagai ibu rumah tangga, terdapat $53,8 \%$ dengan status obstetri multipara dan $84,6 \%$ ibu melahirkan bayi secara spontan. Sedangkan, pada ibu yang tidak diberi propolis $92,3 \%$ berusia $20-35$ tahun, pekerjaan ibu $94,9 \%$ sebagai ibu rumah tangga, ibu dengan status obstetri $71,8 \%$ multi para dan $89,7 \%$ ibu melahirkan bayi secara episiotomi.

\section{Derajat luka perineum}

Derajat luka perineum pada Ibu postpartum yang diberi propolis dan tidak diberi propolis berkisar di derajat 1 hingga 3. Pada ibu yang diberi propolis terbanyak pada derajat $2(61,5 \%)$, sedangkan pada ibu yang tidak diberi propolis terbanyak pada derajat $2(59,0 \%)$. Diperoleh pula derajat luka perineum pada ibu yang diberi propolis dengan rata-rata $=1,82$ sedangkan pada ibu yang tidak diberi propolis dengan rata-rata $=1,85$ (Tabel 2$)$. 
Tabel 1.

Karakteristik Responden pada kelompok eksperimen dan kelompok kontrol

\begin{tabular}{|c|c|c|c|c|c|}
\hline \multirow{2}{*}{ Karakteristik } & \multirow{2}{*}{ Karegori } & \multicolumn{2}{|c|}{ Kelompok Eksperimen } & \multicolumn{2}{|c|}{ Kelompok Kontrol } \\
\hline & & $f(n=39)$ & $\%(100)$ & $f(n=39)$ & $\%(100)$ \\
\hline \multirow[t]{3}{*}{ Usia } & $<20$ tahun & 7 & 17,9 & 3 & 7,7 \\
\hline & $20-35$ tahun & 29 & 74,4 & 36 & 92,3 \\
\hline & $>35$ tahun & 3 & 7,7 & 0 & 0,0 \\
\hline \multirow[t]{3}{*}{ Pekerjaan } & Ibu rumah tangga & 38 & 97,4 & 37 & 94,9 \\
\hline & Wiraswasta & 1 & 2,6 & 1 & 2,6 \\
\hline & PNS & 0 & 0,0 & 1 & 2,6 \\
\hline \multirow[t]{3}{*}{ Status Obstetri } & Primipara & 15 & 36,5 & 9 & 23,1 \\
\hline & Multipara & 21 & 53,8 & 28 & 71,8 \\
\hline & Grande Multi Para & 3 & 7,7 & 2 & 5,1 \\
\hline \multirow[t]{3}{*}{ Jenis persalinan } & $<20$ tahun & 7 & 17,9 & 3 & 7,7 \\
\hline & $20-35$ tahun & 29 & 74,4 & 36 & 92,3 \\
\hline & $>35$ tahun & 3 & 7,7 & 0 & 0,0 \\
\hline
\end{tabular}

Tabel 2.

Distribusi derajat luka perineum pada ibu postpartum yang diberi propolis dan tidak diberi propolis

\begin{tabular}{|c|c|c|c|c|}
\hline \multirow[t]{2}{*}{ Derajat Luka Perineum* } & \multicolumn{2}{|c|}{ Kelompok Eksperimen } & \multicolumn{2}{|c|}{ Kelompok Kontrol } \\
\hline & $f(n=39)$ & $\%(100)$ & $f(n=39)$ & $\%(100)$ \\
\hline Derajat 1 & 11 & 28,2 & 11 & 28,2 \\
\hline Derajat 2 & 24 & 61,5 & 23 & 59,0 \\
\hline Derajat 3 & 4 & 10,3 & 5 & 12,8 \\
\hline *Mean & 1,82 & & 1,85 & \\
\hline
\end{tabular}

\section{Lama penyembuhan luka perineum}

Tabel 3 menunjukkan bahwa lama penyembuhan luka perineum pada Ibu postpartum pada kelompok ekperimen yang diberi propolis berkisar 2 - 6 hari dan terbanyak $(35,9 \%)$ pada hari ke-3 pospartum dengan rerata 3,38 hari. Sedangkan, pada kelompok kontrol yang hanya dilkukan perawatan personal hygiene saat vulva hygiene saja berkisar 5 - 8 hari dan terbanyak $(58,3 \%)$ pada hari ke 7 pospartum dan rata-rata hari sembuhnya 7,10 hari.

Tabel 3.

Distribusi lama penyembuhan luka perineum pada ibu postpartum pada kelompok ekperimen dan kelompok kontrol

\begin{tabular}{lllll}
\hline \multirow{2}{*}{ Lama Penyembuhan Luka Perineum* } & \multicolumn{2}{c}{ Kelompok Eksperimen } & \multicolumn{2}{c}{ Kelompok Kontrol } \\
\cline { 2 - 5 } & $\boldsymbol{f ( n = 3 9 )}$ & $\mathbf{\%}(\mathbf{1 0 0})$ & $\boldsymbol{f}(\mathbf{n}=\mathbf{3 9})$ & $\mathbf{\%}(\mathbf{1 0 0})$ \\
\hline 2 hari & 4 & 10,3 & 0 & 0,0 \\
3 hari & 14 & 35,9 & 0 & 0,0 \\
4 hari & 11 & 28,2 & 0 & 0,0 \\
5 hari & 8 & 20,5 & 2 & 5,1 \\
6 hari & 2 & 5,1 & 4 & 10,3 \\
7 hari & 0 & 0,0 & 21 & 53,8 \\
8 hari & 0 & 0,0 & 12 & 30,8 \\
\hline \multicolumn{4}{c}{} \\
\hline
\end{tabular}

\section{Hasil bivariat}

Tabel 4 memperlihatkan bahwa rata-rata lama penyembuhan luka perineum pada ibu pospartum yang diberi propolis adalah 3,38 hari (SD 0,935). Sedangkan, untuk ibu yang tidak diberi propolis ratarata penyembuhan luka perineumnya adalah 7,10 hari $(S D \pm 0,788)$. Hasil uji statistik didapatkan p value $=0,000$, berarti pada alpha 5\% menunjukkan ada perbedaan lama penyembuhan luka perineum ibu 
pospartum antara yang diberi propolis dan yang tidak diberi propolis. Artinya luka perineum pada ibu postpartum yang diberi propolis lebih cepat sembuh dibanding dengan yang tidak diberi propolis.

Tabel 4.

Pengaruh pemberian propolis terhadap lama penyembuhan luka perineum pada ibu postpartum

\begin{tabular}{llllll}
\hline \multicolumn{1}{c}{ Lama Penyembuhan Luka Perineum } & n & Mean & SD & SE & P value \\
\hline Kelompok eksperimen & 39 & 3,38 & 0,935 & 0,150 & \multirow{2}{*}{0,000} \\
Kelompok kontrol & 39 & 7,10 & 0,788 & 0,126 & \\
\hline
\end{tabular}

\section{Pembahasan}

\section{Derajat luka perineum pada ibu postpartum}

Hasil penelitian diperoleh bahwa derajat luka perineum pada Ibu postpartum yang diberi propolis dan tidak diberi propolis berkisar di derajat 1 hingga 3. Derajat luka perineum terbanyak pada derajat 2 dimana pada kelompok ibu yang diberi propolis sebesar $61,5 \%$ dan pada kelompok ibu yang tidak diberi propolis sebesar 59,0\%. Diperoleh pula rata-rata derajat luka perineum pada kelompok ibu yang diberi propolis sebesar 1,82 sedangkan pada ibu yang tidak diberi propolis sebesar 1,85. Hasil penelitian ini hampir sama dengan penelitian oleh Nugraheny \& Heriyat (2014) dalam penelitiannya di BPM Anastasia Darwati Jetis Bantul menemukan dari 72 ibu pospartum yang mengalami ruptur perineum derajat 2 sebanyak $84,7 \%$.

Perineum merupakan daerah antara kedua belah paha yang dibatasi oleh vulva dan anus (Ambarwati, 2010). Rupture adalah luka pada perineum yang diakibatkan oleh rusaknya jaringan secara alamiah karena proses desakan kepala janin atau bahu pada saat proses persalinan. Bentuk rupture biasanya tidak teratur sehingga jaringan yang robek sulit dilakukan penjahitan (Damayanti, dkk., 2014). Luka/robekan perineum adalah luka pada daerah perineum yang disebabkan oleh tindakan episiotomy dan dapat juga terjadi secara alami karena pada saat proses persalinan, kurang adanya perlindungan terhadap perineum, sehingga kepala bayi dan tekanan meneran ibu dapat merobek jaringan perineum dan sekitarnya (Prawirohardjo, 2008).

Hasil penelitian ini juga menemukan bahwa ruptur perineum pada ibu postpartum sebagian besar terjadi secara spontan dimana $84,6 \%$ terjadi pada ibu yang diberikan propolis dan $89,7 \%$ pada ibu yang tidak diberi propolis. Hal sesuai dengan yang dikemukakan oleh Chapman (2006) bahwa perlukaan perineum merupakan perlukaan yang terjadi pada perineum saat persalinan dan $70 \%$ terjadi pada wanita yang melahirkan pervaginam. Derajat luka merupakan penilaian yang wajib dilakukan oleh penolong persalinan jika persalinan terjadi ruptur baik dilakukan dengan sengaja oleh penolong persalinan yang diseput dengan tindakan episiotomi ataupun terjadi karena ruptur spontan. Hal ini sangat menentukan trauma perineum yang berhubungan dengan struktur anatomis yang terlibat termasuk penatalaksanaannya.

Penelitian ini memperoleh hasil derajat luka perineum terbanyak pada derajat 2 dengan rata-rata derajat luka perineum pada kelompok ibu yang diberi propolis sebesar 1,82 sedangkan pada ibu yang tidak diberi propolis sebesar 1,85. Hasil penelitian ini juga menunjukkan bahwa liserasi atau perlukaan perineum ini terjadi pada ibu primipara 36,5\% (15) pada kelompok ibu yang diberi propolis dan $23,1 \%$ (9) terjadi pada ibu yang tidak diberi propolis. Hal ini sesuai dengan yang dikemukakan oleh Wiknjosastro, dkk., (2010), bahwa robekan perineum terjadi pada hampir semua persalinan pertama dan tidak jarang juga pada persalinan berikutnya dikarenakan teknik mengedan yang salah, bayi besar atau kerena perineum kaku.

Bidan sebagai tenaga penolong persalinan sesuai Depkes RI (2007), kewenangan bidan dalam penjahitan luka ruptur perineum hanya pada derajat satu dan dua, sedangkan untuk derajat ketiga atau 
keempat sebaiknya bidan melakukan kolaborasi atau rujukan ke rumah sakit, karena ruptur ini memerlukan teknik dan prosedur khusus.

\section{Lama penyembuhan luka perineum pada ibu postpartum}

Hasil penelitian menunjukkan lama penyembuhan luka perineum pada Ibu postpartum yang diberi propolis berkisar 2 - 6 hari dan 35,9\% terbanyak pada hari ke 3 pospartum dan rata-rata hari sembuhnya 3,38 hari. Sedangkan, pada ibu yang tidak diberi propolis berkisar $5-8$ hari dan $58,3 \%$ terbanyak pada hari ke 7 pospartum dan rata-rata hari sembuhnya 7,10 hari.

Hasil penelitian ini lebih rendah dari yang ditemukan oleh Suyati, Azizah \& Ninik (2014), dalam penelitiannya yang dilakukan di Bidan Umi Salamah Petorongan Jombang bahwa dari 20 ibu pastpartum sebagai kelompok perlakukan penyembuhan luka perineum pada hari ke 7 sebanyak $60 \%$ dengan hasil baik dan sedangkan kelompok kontrol dari $20 \mathrm{ibu}$ potpartum penyembuhan luka perineum hari ke 7 sebanyak 45\% dengan hasil baik. Penelitian oleh Rohmin, Baity \& Morlina (2017) di BPM Maimunah Palembang dari 128 ibu postpartum lama penyembuhan luka perineum $\leq 7$ hari sebanyak $62,5 \%$. Sedangkan, sembuh 7 hari $37,5 \%$ dan Afandi (2014) memperoleh $76 \%$ ibu postpartum mengalami percepatan penyembuhan luka perineum baik.

Lama penyembuhan perineum adalah waktu yang diukur sejak penjahitan perineum sampai luka menutup, kering dan tidak ada tanda-tanda infeksi antara lain merah, bengkak, panas dan nyeri (Ambarwati, 2010). Lama penyembuhan luka perineum yang baik adalah 6-7 hari setelah persalinan (Mochtar, 2015). Luka dinyatakan sembuh apabila luka kering, tidak ada kemerahan, tidak ada pembengkakan, jaringan menyatu dan tidak nyeri ketika untuk duduk dan jalan. Penyembuhan luka perineum yang lama akan meningkatkan resiko terjadinya infeksi pada masa nifas (Rukiyah, 2010).

Faktor-faktor yang mempengaruhi penyembuhan luka perineum antara lain adalah ibu tidak mengalami kelainan misalnya anemia dan diabetes mellitus, kebutuhan gizi ibu tercukupi dilihat dari IMT ibu, pegetahuan ibu mengenai perawatan luka perineum ibu baik, personal hygiene ibu baik selama masa nifas, ibu melakukan mobilisasi dini 2 jam setelah persalinan pada ibu tidak ada komplikasi (Wiknjosastro, 2010). Bidan sebagai penolong persalinan sesuai dengan kompetensinya perlu melakukan penilaian dengan cermat terhadap lamanya penyembuhan luka perineum pada postpartum sehingga segera diambil tindakan yang tepat agar tidak terjadi komplikasi pada masa nifas yang mengakibatkan penyembuhan luka perineum lambat.

\section{Pengaruh pemberian propolis terhadap lama penyembuhan luka perineum pada ibu postpartum}

Hasil penelitian ini menunjukan bahwa rata-rata lama penyembuhan luka perineum pada ibu pospartum yang diberi propolis adalah 3,38 hari dengan Standar Deviasi 0,935. Sedangkan, untuk ibu yang tidak diberi propolis rata-rata penyembuhan luka perineumnya adalah 7,10 hari dengan Standar Deviasi 0,788 . Terdapat pengaruh lama penyembuhan luka perineum ibu pospartum antara yang diberi propolis dan yang tidak diberi propolis $(p$-value $=0,000)$. Penyembuhan luka perineum pada ibu postpartum yang diberi propolis lebih cepat 4 hari dibanding dengan yang tidak diberi propolis.

Hasil penelitian ini sesuai dengan penelitian yang dilakukan oleh Suyati, \& Ninik (2014) di Bidan Umi Salamah Petorongan Jombang yang menunjukkan bahwa penyembuhan luka perineum pada ibu post partum yang diberikan propolis setelah diobservasi selama 7 hari, sebagian besar (80\%) dalam keadaan baik, yaitu sebagian besar luka sudah tampak kering, menutup dan tidak ada tanda-tanda infeksi. Hasil analisis diperoleh ada pengaruh propolis terhadap penyembuhan luka perineum pada ibu post partum ( $p$-value 0,024). Hasil penelitian ini juga didukung oleh penelitian Kivalkina, Gorshunova, \& Kazan (2011) tentang efek kombinasi antibiotik dan propolis didapatkan hasil bahwa propolis meningkatkan aktivitas bakteriostatik (kemampuan membunuh bakteri) antibiotik sebanyak 10-100 
kali lipat terhadap bakteri dan propolis juga meningkatkan aktivitas antimikroba saleb antibiotic (Kivalkina, Gorshunova, \& Kazan, 2011).

Beberapa penelitian yang berkaitan dengan lama penyembuhan luka perineum pada ibu postpartum menggunakan perlakuan yang berbeda-beda juga telah banyak dilakukan. Penelitian yang dilakukan oleh Astuti, Puji, \& Warsiti (2015) di BPS Pipin Herysanti dan BPS Walginem yogyakarta, hasilnya menunjukkan rata-rata lama penyembuhan luka perineum yang menggunakan povidone iodine yaitu 7,4 hari. Penelitian yang dilakukan Ranggeriani \& Lamdayani (2018) di BPM Sagita Kota Palembang menemukan rata-rata penyembuhan luka perineum pada ibu postpartum yang diberikan daun sirih (Piper betle L) 5,47 hari. Penelitian Rizka (2019) yang dilakukan di BPM Eka Santi Brabekti dan Sulistiyo Rahayu Lampung Tengah juga menemukan rerata ibu postpartum yang diberikan madu menunjukkan luka perineum sembuh 6,57 hari. Dari beberapa penelitian yang telah diuraikan menunjukan bahwa pemberian propolis memiliki waktu penyembuhan lebih efektif untuk menyembuhkan luka perineum pada ibu pospartum.

Penilaian penyembuhan luka pada daerah luka yang berhubungan dengan trauma perineum setelah persalinan. REEDA menilai lima komponen proses penyembuhan dan trauma perineum setiap individu. Penilaian sistem REEDA meliputi redness tampak kemerahan pada daerah penjahitan, edema adalah adanya cairan dalam jumlah besar yang abnormal di ruang jaringan intraselular tubuh, menunjukkan jumlah yang nyata dalam jaringan subkutis, edema dalam terbatas yang disebabkan oleh obstruksi vena atau saluran limfatik atau oleh peningkatan permeabilitas vaskular. Ecchymosis adalah bercak perdarahan yang kecil, lebih lebar dari petekie (bintik merah keunguan kecil dan bulat sempurna tidak menonjol), pada kilit perineum membentuk bercak biru atau ungu yang rata, bulat atau tidak beraturan. Discharge adalah adanya ereksi atau pengeluaran dari daerah yang luka perineum. Approximation adalah kedekatan jaringan yang dijahit (Bick, 2010).

Propolis merupakan zat resin yang dihasilkan oleh lebah dan merupakan percampuran dari air liur lebah, lilin lebah, dan juga bahan yang bersumber dari tanaman yang dibawa oleh lebah (Swari, 2016). Propolis atau lem lebah adalah suatu zat yang dihasilkan oleh lebah madu. Dikumpulkan oleh lebah dari pucuk daun-daun yang muda untuk kemudian dicampur dengan air liurnya dapat digunakan untuk menambal dan mensterilkan sarang. Secara umum, propolis memiliki kurang lebih 300 kandungan senyawa kimia, salah satu yang paling dominan adalah polifenol. Senyawa ini merupakan antioksidan yang sangat baik untuk menangkal berbagai radikal bebas dan juga berbagai penyakit. Kandungan lain dalam propolis membuat propolis memiliki sifat antibakeri, antivirus, antifungal dan anti inflamasi (Novita, 2019). Propolis bersifat disinfektan (anti bakteri) yang membunuh semua kuman yang masuk ke dalam sarang lebah. Sifat disinfektan alami yang terkandung dalam propolis sangat ampuh dalam membunuh kuman antioksidan (Bina ..., 2008).

Propolis sebagai pengobatan alami mengandung zat aktif yang berfungsi sebagai obat untuk berbagai macam penyakit. Propolis mengandung zat-zat yang dibutuhkan untuk membangun kekebalan tubuh dan mengaktifkan kelenjar thymus. Zat-zat tersebut adalah propolis mengandung semua vitamin kecuali vitamin $\mathrm{K}$, propolis mengandung semua mineral yang dibutuhkan tubuh kecuali sulfur. Propolis mengandung 16 rantai asam amino esensial yang dibutuhkan untuk regenerasi sel, mengandung bioflavanoid, yaitu zat antioksidan sebagai suplemen sel. Menurut penelitian, kandungan bioflavonoid pada satu tetes propolis setara dengan bioflavonoid yang dihasilkan dari 500 buah jeruk (Bina ... , 2008). Beberapa khasiat propolis yang masih dimanfaatkan hingga saat ini adalah untuk mempercepat penyembuhan luka. Selain itu, sebagai antikanker, meringankan nyeri akibat herpes genital, meingkatkan daya tahan tubuh, menurunkan kolesterol jahat dan tekanan darah tinggi, sebagai obat kumur, dan sebagai perawatan kulit (Pusat ..., 2018).

Hasil penelitian ini memberikan implikasi dalam asuhan pada ibu post partum dengan luka perineum bahwa propolis mempercepat proses penyembuhan luka perineum. Bidan, tenaga kesehatan 
lain dan masyarakat, khususnya ibu post partum dapat memanfaatkan terapi komplementer, seperti propolis untuk perawatan luka perineum, sehingga waktu perawatan lebih pendek.

\section{Simpulan dan Saran}

Luka perineum pada ibu postpartum yang diberi propolis akan lebih cepat sembuh dibanding dengan yang tidak diberi propolis. Upaya mempercepat penyembuhan luka perineum oleh Bidan, Tenaga kesehatan lain maupun ibu postpartum dapat memanfaatkan propolis sebagai salah satu terapi komplementer.

\section{Ucapan terima kasih}

Tidak ada.

\section{Referensi}

Afandi, M., Suhartatik, S., \& Ferial, E. (2014). Hubungan mobilisasi dini dan personal hygiene terhadap percepatan kesembuhan luka perineum pada ibu post partum di RSIA Pertiwi Makassar. Jurnal Ilmiah Kesehatan Diagnosis, 5(3), 295-301. $\quad$ Retrieved from http://ejournal.stikesnh.ac.id/index.php/jikd/article/view/759

Ambarwati, E. R. (2010). Asuhan kebidanan nifas. Jogjakarta: Nuha Medika

Anggeriani, R. \& Lamdayani, R. (2018). Efektifitas pemberian air daun sirih (piper betle 1) terhadap kecepatan penyembuhan luka perineum pada ibu postpartum. Jurnal'Aisyiyah Medika. 9(1). Retreived from http://jurnal.stikes-aisyiyah-palembang.ac.id/index.php/Kep/article/view/121

Astuti, Puji, S. A., \& Warsiti. (2015) Perbedaan lama penyembuhan luka perineum antara yang diberi povidone iodine dan tidak diberi povidone iodine pada ibu postpartum di BPS Pipin Heriyanti dan BPS Walginem. Retreived from http://digilib.unisayogya.ac.id/1414/

Bick. (2010). Pemeriksaan fisik Reeda dengan menggunakan Reeda scale. Retreived from https://www.perawatkitasatu.com/2017/08/pemeriksaan-fisik-reeda.html

Bina ... (2008). Propolis sang penyembuh luar biasa. Peternakan Lebah Bina Apiari Indonesia. Retreived from http://www.binaapiari.com.

Chapman, V. (2006). Asuhan kebidanan persalinan dan kelahiran. Jakarta: EGC.

Damayanti, I. P., dkk. (2014). Buku ajar asuhan kebidanan komprehensif pada ibu bersalin dan bayi baru lahir. Ed.1, Cet. 1. Yogyakarta: Deepublish.

Departemen Kesehatan RI. (2007). Asuhan persalinan normal. Jakarta: JNPK-KR.

Dinas Kesehatan Provinsi Lampung (2016). Profil kesehatan provinsi Lampung tahun 2015. Bandar Lampung: Dinkes Provinsi Lampung

Fraser \& Cooper. (2009). Buku ajar bidan meyles. Edisi 14. Jakarta: EGC.

Kivalkina, V. P., \& Gorshunova, V. I. (2011). Penelitian efek kombinasi antibiotik dan propolis. Retreived from http://propolis.blogspot.com

Manuaba, I. A. C., dkk., (2010). Ilmu kebidanan, penyakit kandungan, dan KB untuk pendidikan bidan. Edisi 2. Jakarta: ECG

Mochtar, R. (2015). Sinopsis obstetry Jilid 2 Edisi 3. Jakarta: EGC

Murti, B. (2016). Prinsip dan metode riset epidemiologi Edisi ke-empat. Colomadu Karanganyar, Jawa Tengah: PS IKM UNS Bintang Fajar Offset.

Novita, J. (2019). Propolis melia obat apa, dosis, fungsi, dll. Retreived from https://hellosehat.com.

Nugraeny, E. \& Heriyat, H. (2014). Faktor-faktor yang mempengaruhi terjadinya rupture perineum pada ibu bersalin normal. Jurnal Ilmu Kebidanan (JIK). 4(1). Retreived from http://jurnalilmukebidanan.akbiduk.ac.id/index.php/jik/article/view/70 
Oxorn, H. (2010). Ilmu kebidanan: patologi dan fisiologi persalinan. Human. Labor and birth. Jakarta: Yayasan Essentia Medica

Prawirohardjo, S. (2008). Ilmu kesehatan maternal dan neonatal. Jakarta: YBP- SP.

Rahayu, M. I. (2018). Propolis: kandungan, manfaat, efek samping. Retreived from https://doktersehat.com/obatpropolis/

Pusat ... (2018). Perbedaan obat propolis asli dan palsu. Retreived from https://pusatpropolis.id/perbedaan-obatpropolis-asli-dan-palsu/

Rahmawati. (2011). Hubungan berat badan lahir dengan derajat rutur perineum pada persalinan normal di RSIA Kumala Siwi Pencangaan Jepara. Jurnal Kesehatan dan Budaya. 4(1).

Rizka, P. F. (2019). Efektifitas daun sirih dan madu terhadap lamanya penyembuhan luka perineum pada Ibu Nifas. Skripsi. Prodi Kebidanan Metro Poltekkes Tanjungkarang.

Rohmin, A., Oktariani, B., \& Jania, M. (2017). Faktor risiko yang mempengaruhi lama penyembuhan luka perineum pada ibu post partum. Jurnal Kesehatan (JK), 8(3). DOI: http://dx.doi.org/10.26630/jk.v8i3.660

Rukiyah, dkk., (2010). Asuhan kebidanan II. Jakarta: CV. Trans info media.

Sastroasmoro, S. \& Ismeal, S. (2014). Dasar-dasar metodologi penelitian klinis. Edisi 5. Jakarta: PT. Sagung Seto.

Suyati, \& Ninik, A (2014). Pemanfaatan Propolis dalam Penyembuhan Luka. Jurnal EduHealth. 4(1). Retreived from https://journal.unipdu.ac.id/index.php/eduhealth/article/view/445

Swari, C. (2016). Manfaat propolis, getah lebah yang penuh khasiat (tidak kalah dari madu). Retreived from: https://hellosehat.com/hidup-sehat/tips-sehat/manfaat-propolis-untuk-kesehatan.

Winkjosastro, H. (2010). Ilmu kandungan. Edisi II. Cetakan Kelima. Jakarta; Yayasan Bina Pustaka Sarwono Prawirohardjo

Sitasi: Lestari, G. I, Ridwan, M., \& Fibrila, F (2020). Pemberian propolis terhadap mempercepat penyembuhan luka perineum pada ibu postpartum. Jurnal Kesehatan Metro Sai Wawai. 13(1). 27-35. DOI: $10.26630 / \mathrm{jkm} . \mathrm{v} 13 \mathrm{i} 1.1973$

Hiperlink DOI: http://dx.doi.org/10.26630/jkm.v13i1.1973 